\title{
Innovative Aspects of a Sustainable Regional Development
}

\author{
Galina Merzlikina \\ Volgograd state technical University \\ Faculty of Economics and Management \\ Volgograd, Russia \\ merzlikina@vstu.ru
}

\author{
Ekaterina Kuzmina \\ Volgograd state technical University \\ Faculty of Economics and Management \\ Volgograd, Russia \\ katerina993@yandex.ru
}

\begin{abstract}
The article substantiates the need to create a methodology for the formation of a program of sustainable innovative development of the region, including the consistent implementation of the stages of assessing the innovative potential of the region, technology transfer, activation of innovation for regional development. The availability of productive, economic and social resources is determined as the main and significant condition for the effective implementation of the methodology for the formation of a sustainable regional development program. With the interaction of structural components, it is possible to transform resources into innovation technology. Only in the case of sharing the results of scientific activity is the transformation of innovation into an innovative product or innovative technology. Therefore, the priority direction of sustainable regional development is to stimulate interaction and exchange of technologies and results of scientific activities.
\end{abstract}

Keywords - innovative development, regional development, regional territorial unit, sustainable regional system, indicators of innovative development, regional potential, methods of forming a regional development program, the results of scientific and technical activities, activation of innovative regional development, innovative projects, innovative enterprises

\section{INTRODUCTION}

Under current conditions the question about the economic transformation at the micro- and macro-levels to innovationbased growth is of the most immediate interest. The major premise to shift towards the innovation economy is a resourcebased economy of today that hinders the improvment of the essential economic, operational and social indicators of country performance and that places under a threat the sustainable development of economic systems.

It seems to be impossible to increase the GDP and to become more competive on the global market in the context of the current innovation conjuncture. The need for expanding the innovative potential of the country and its regions is evident.

In order to establish and develop an innovative economy, it is necessary to develop a mechanism that will facilitate the restructuring and interaction of all production and infrastructure elements contributing to the innovative development of the economy on a national scale and at the regional level in particular. The process of transition to innovative development of the economy is based on the formation of an integrated and unified system that will facilitate the converting and transformation of new knowledge into new technologies, goods, products and services.

Therefore, for innovative sustainable development of the region, an evaluation mechanism is needed that will identify the potential opportunities of the region and likewise improve financial stability, investment attractiveness and competitiveness.

\section{MATERIALS AND METHODS (MODEL)}

The methodology for the designing and making up a program of innovative sustainable regional development presupposes taking into account the specifics of territorial and economic features, the regional development level, as well as the correlation between the technological structures of the economy within a particular territory. The successful implementation of the created program of innovative sustainable regional development results in the increase of the financial stability and competitiveness of the region.

In order to implement the methodology for designing a program of innovative sustainable regional development, it is necessary to take an assessment of the following indexes:

- $\quad$ regional innovative potential;

- indicators of innovative development of the region.

The methodology for the forming a program of innovative sustainable regional development includes three consecutive stages, i.e. this is an assessment of the innovative activity of regional development, the exchange of results of scientific and technical activities, the implementation of promoted steps towards the innovative regional development.

Thus, the methodology for the establishing of the innovative sustainable regional development program is determined by inverse relationship that helps to clarify the order or to add some new measures of implementation of the 
innovative regional program due to a dynamic environment of the region.

\section{RESULTS AND DISCUSSION}

The regional economy is one of the main elements of the national economic complex. This fact means that the regional economy plays an important strategic role at the macroeconomic level in terms of identifying the potential for economic development and growth generally. The increase in macroeconomic indicators of the national economy shows a direct correlation between the sustainable development of the regional economic units and the whole economic system. The issue of determining and using the competitive advantages of production and material resources is being solved at the regional level indeed.

In terms of identifying competitive advantages at the level of the national economy, the key area of analysis is the region itself in the context of its sustainable development. The region can be defined as a structural administrative territorial unit within the national economic complex characterized by complex organization of production management and administration.

The main aspects of the regional economy that ensure its equation are presented below:

- $\quad$ economic, financial and social conditions for identifying and using the potential of the particular economic entity;

infrastructure;

development of production and production production sphere;

the relationship between the subjects of the

- identification and effective use of the advantages of the regional unit in regard to other economic entities.

The specific feature of a regional territorial unit is the multiple characteristic of its structural system. The constituent structural elements of the region build population and social infrastructure, material and resource base, production and technological complex, management and information technology.

According to the reported published data of the Russian Federal State Statistics Service (Rosstat), there is a slight growth or even a decline in the following indicators characterizing the production and innovation components:

- growth (decrease) in industrial production amounted to $-3.4 \%$ at the end of 2015, and in 2016 growth was $0.4 \%$;

- $\quad$ index of the physical quantity of the gross domestic product (GDP) at the end of 2016 reached $99.8 \%$, conformable to $101.5 \%$ at the end of 2017 ;

- the share of high-tech and knowledge-intensive industries in the gross domestic product (GDP) amounted to $22 \%$ in 2016 in comparison with $22.1 \%$ at the end of 2017.
In aggregate, all the constituent structural elements of the region are interrelated and to a greater or lesser extent affect each other. However, in aggregate all elements build a whole in the form of a sustainable regional system.

Most aspects of sustainable development, despite a significant number of publications, are insufficiently disclosed and developed.

As a result of the UN Conference, a definition of a sustainable development was formulated, whereby this term includes three interrelated elements: economic efficiency, social equity and environmental sustainability [1].

O. S. Pchelintsev notes that the development of the region is considered as an expanded concept of integrated regional development, i.e. as a "transition from intra-regional linkage of individual industries to systemic management of the whole complex of economic, socio-demographic and ecological processes within the the particular territory" [1].

According to V.A. Koptyug, the sustainable development involves "achieving a reasonable balance of the socioeconomic development of mankind and the preservation of the environment"[2].

The concept of sustainable regional development refers to the integration of sustainable development principles into regional development practice. We use the term "sustainable regional system" to mean correlation of production, economic, financial and social elements, located in the subject's territory.

A sustainable regional development is directly dependent on external and internal factors that can take various forms. To the most significant and relevant factors of the sustainable regional development refer the following ones:

$$
\begin{array}{ll}
\text { - } & \text { presence of material and resource base; } \\
\text { - } & \text { management infrastructure; } \\
\text { - } & \text { instruments and programs of state support; } \\
\text { - } & \text { economicion of concessionary financing; } \\
\text { - } & \text { development of an individual innovation } \\
\text { development strategy. }
\end{array}
$$

Among the factors considered, innovation development, reflecting the industrial and technological transformations of the region, is especially significant.

It is innovative development that determines the parameters of regional aspects of production, ensuring economic and social development of the region's economy, which ultimately should increase its financial stability.

The innovative development of the region is one of the courses of the comprehensive development program, which includes the growth of production, modernization of infrastructure, development of non-productive sector, as well as the social component [4].

The main condition for the implementation of sustainable regional development is existence of a complex of technological and material resources, as well as an economic 
and production system. The interaction of the availability of resources and the production system allows the transformation of resources into an innovative product or technology. The combination of the two elements reflects the degree of regional development potential and represents an innovative potential itself.

Thus, the efficiency of innovative sustainable regional development depends on the level of innovation potential.

Consequently, the main objective of innovative sustainable regional development is to increase the degree of innovation in the economy. To increase the innovativeness in the region's economy is possible by creating production structures based on technologies, using highly intellectual labor and creating a high added value of the product.

The foregoing allows us to conclude that innovative regional development is determined by the actions of certain business entities, as well as on "how they interact with each other as elements of a collective system for creating and using knowledges, as well as with public institutions (such as values, norms, law)" [3].

Innovative sustainable regional development is based on the following principles:

- $\quad$ a sustainable development based on innovation is present when there is an innovative environment in the region;

- the process of innovative sustainable development of the region is carried out through the formation of an innovative system of the territorial unit;

- as the ground for innovative sustainable development serves demand to increase economic and social development indicators;

- $\quad$ planning and developing a regional innovation policy at the level of local governments;

- there are production facilities and material resources in the region in order to implement innovation policy.

Taking into consideration the abovementioned principles, it is possible to outline and develop an effective methodology for the formation of an innovative program for the sustainable regional development. At the same time, the methodology should pay regard to the specifics of economic and territorial features, the degree of development of the regional entitiy, the proportion between the production and technological infrastructure of the economy.

The methodology for formation an innovative program for the sustainable regional development can be fulfilled by the consistent implementation of four stages.

At the first stage, an innovative component of regional development is assessed. Innovative potential of the region is an integral part of the economic, productive and social potential of the country's economy in general.

To determine a potential level we have to measure the performance according to the following steps:
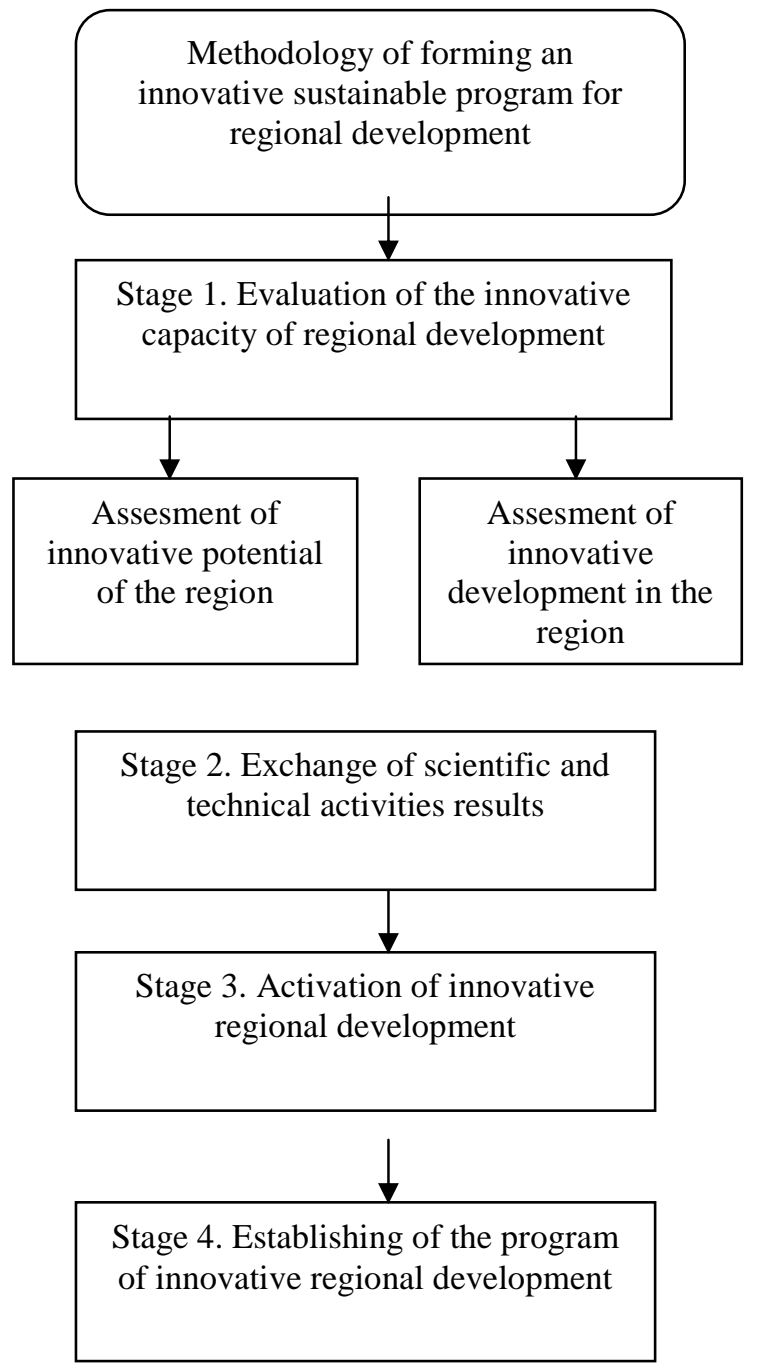

Fig. 1. Methodology of forming a sustainable regional development program.

Evaluation of regional innovative potential. For this purpose innovative programs and projects feasibility is used: matching analysis of production and economic resources against the investment volume in order to implement the strategy of innovative regional development.

Evaluation of the innovative development measures: the costs of technical and technological renewal, science intensity, marketing costs, the number of innovative products in regard to the gross regional production, the volume of exports of innovative products.

At the second stage, the results of scientific and technical activities are exchanged. Through the exchange new technologies and knowledge are transformed into innovative products, goods and services indeed.

As a result of the exchange, economic, productive and financial indexes are growing. Improving the exchange methodology is considered as a national program because it affects the changes in the economic situation in general and some aspects of federal legislation 
The strategic orientation by the establishing a program to enhance the exchange of scientific and technical results at the regional level is determined by the following factors.

First of all, the economic, financial and social conditions for creating a basis for the development of an innovative component at the level of each region are very different. It means that it is not possible to unify the processes of exchanging scientific results across the country.

When developing an effective program to stimulate the exchange of innovations and new technologies at the regional level, one should take into account the inequality of the innovative potential, as well as the structure, the resource base and infrastructure, the financial capacity of the regional budget.

Secondly, cooperation of entrepreneurs, representatives of local government and scholars in place will contribute to the smart adaptation to some external factors and add to competitive advantages

Thirdly, the main priority of the innovation sphere should be an increase of innovations within small and medium-sized businesses. This is what shapes the object-orientation by management of the innovations and new technologies exchange at the regional level.

Taking into account the above-mentioned peculiarities of regional entities, there is need of a particular program to stimulate the exchange of innovations and results of scientific activity, which would cover the level and structure of innovative development and innovative potential of the region.

For the exchange of scientific research data and results of technical activity, the following methods can be used:

$\begin{array}{ll}- & \text { patents; } \\ \text { - } & \text { inventions without patenting; } \\ \text { - } & \text { licensing; } \\ \text { - } & \text { enginow-how"; } \\ \text { - } & \text { sharing of best practices between the scientists; } \\ \text { tests; } & \text { joint studies, collaborative work and laboratory } \\ - & \text { holding of research workshops and seminars. }\end{array}$

At present time, the exchange of scientific and technical results in the country does not demonstate high efficiency for a number of reasons:

- a lot of research studies are carried out within the public sector;

- low innovative development in the sphere of small business;

- the lack of the commercialization of innovative development results;

- the lack of reliable and complete information on existing scientific and innovative developments in the scientific world among industrial large and medium-sized enterprises;

- the lack of legislative and regulatory framework in the field of commercialization of innovative development results and solutions.
Creating of stimulative mechanisms for the exchange of scientific research data and technical results at the regional level is the basis for innovative sustainable regional development generally.

At the third stage, it is necessary to intensify innovative regional development. In order to activate the innovative development of the region, it is necessary to form an innovative infrastructure (clusters, technology parks, business incubators), as well as to finance innovative projects.

To activate the innovative regional development, it is necessary to create a complex of innovative enterprises. The main areas of work of such enterprises should include the attraction of investments for the implementation of innovative projects. In addition, the task of such enterprises will include the collection and processing of information on the innovative environment of the region, the generation of planned and already implemented innovative projects.

The creation of a complex of innovative enterprises at the regional level will provide the balance of the innovation sphere at the regional level and the using of innovative potential by increasing the infrastructure. The development of a complex of innovative enterprises in the region will make it possible to produce innovative assets, which will increase the economic and social indexes of the region, while creating a competitive advantage for the regional economy.

At the fourth stage, a program of innovative sustainable regional development is being developed.

The establishing of the program of innovative regional development should proceed at the national level, as it might affect some changes in federal legislation.

Creating of an innovative sustainable regional development program includes a set of actions aimed at the development of innovative entrepreneurship, as well as the promotion of commercialization of scientific and technical research activities results. Local government bodies should prepare a system of tax concessions for organizations that perform research and development, improve the legislative framework for the regulation of intellectual property rights.

\section{CONCLUSION}

Thus, to innovate the economy, it is necessary to use the methodology for creating an innovative sustainable regional development program that takes into account the specific characteristics of the particular entity such as territorial and economic conditions, the level of development of the region, the availability of technological, industrial and material resources.

In the process of implementing the innovative regional development mechanism, an assessment of the innovative potential is conducted, which makes possible to determine the strategic directions of regional growth.

One of the direction of innovative sustainable regional development is the creation of a complex of innovative enterprises that will help to activate and to commoditize new technologies, research and developments. 
Using the methodology of an innovative development program forming will contribute to the financial stability and competitiveness of the region.

\section{References}

[1] Pchelintsev O. S. Regional economy in the system of sustainable development. Moscow: Science, 2004, 258 р. [Пчелинцев О.С. Региональная экономика в системе устойчивого развития. М.: Наука, 2004, 258 c].

[2] Koptyug, V. A. United Nations Conference on environment and development (Rio de Janeiro, June 1992) review of the Information. Novosibirsk, 1992. - P. 19-20. [Коптюг В.А. Конференция ООН по окружающей среде и развитию (Рио-де-Жанейро, июнь 1992 г.) Информационный обзор. - Новосибирск, 1992. - С.19-20]

[3] Smith K. The Systems Challenge to Innovation Policy. In: Polt W. Weber B. (eds). Industrie und Glueck. Paradigmenweechsel in der Industrie-und Technologiepolitik. Vienna. 1996.

[4] Grishchenko, V. A. the Mechanism of implementation of cluster innovation policy in the Volga Federal district / V. A. Grishchenko // Voprosy ekonomicheskikh nauk. - 2007. - №5 (23), Pp. 126-138. [Грищенко, В.А. Механизм реализации кластерной инновационной политики в Приволжском федеральном округе / В.А. Грищенко // Вопросы экономических наук. - 2007. - №5(23), С.126-138]. 